\title{
ANTICONVULSANT PROPERTIES OF SOME MEDICINAL PLANTS: A REVIEW
}

\author{
NIVEDHA SRINIVASAN ${ }^{1}$, ANITHA ROY ${ }^{2 *}$ \\ ${ }^{1}$ Department of Dental Surgery, Saveetha Dental College and Hospitals, Chennai, Tamil Nadu, India. ${ }^{2}$ Department of ???, Faculty of \\ Pharmacology, Saveetha Dental College and Hospitals, Chennai, Tamil Nadu, India. Email: anitharoy2015@gmail.com
}

Received: 04 August 2016, Revised and Accepted: 25 October 2016

\begin{abstract}
Introduction: Epilepsy is the tendency to have seizures that start in the brain. The brain uses electrical signals to pass messages between brain cells and when these signals are disrupted, it leads to a seizure. A number of synthetic antiepileptic drugs are available in practice, but various medicinal plants act as an important source of treatment for epilepsy; plants such as Aeollanthus suaveolens, Passiflora caerulea, Persea americana, Annona diversifolia, and Boerhavia diffusa have good anticonvulsant activity.
\end{abstract}

Objective: Anticonvulsant drugs are used to control the convulsions by inhibiting the discharge and then producing hypnosis. The objective is to understand various medicinal plants and plant components, which are being used as an anticonvulsant.

Results: A. suaveolens essential oils are the main constituents were deemed to display anticonvulsant activity. $P$. caerulea is reputed to have herbal activity as a sedative and anticonvulsant and it is often used as a relatively disease resistant root stock. Whereas $P$. americana, extract produces its anticonvulsant effect by enhancing gamma-aminobutyric acid ergic neurotransmission and or action in the brain. B. diffusa consists of a calcium channel antagonist compound, liriodendrin that is responsible for its anticonvulsant activity.

Conclusion: Since epilepsy has become a common brain disorder, having knowledge of the medicinal plants with an anticonvulsant activity will be beneficial to the society.

Keywords: Antiepileptic, Aeollanthus suaveolens, Passiflora caerulea, Persea americana, Annona diversifolia, Boerhavia diffusa.

(C) 2017 The Authors. Published by Innovare Academic Sciences Pvt Ltd. This is an open access article under the CC BY license (http://creativecommons. org/licenses/by/4. 0/) DOI: http://dx.doi.org/10.22159/ajpcr.2017.v10i2.14501

\section{INTRODUCTION}

Epilepsy is the tendency to have seizures that start in the brain. The brain uses electrical signals to pass messages between brain cells and when these signals are disrupted and it leads to a seizure [1]. According to the WHO, about 450 million people in the entire world have suffered mental, neurological, or behavioral problems out of which $1-2 \%$ has had epileptic seizures [2]. Seizures are divided into two main types; generalized and focal. Generalized seizures occur if the abnormal electrical activity affects all or most of the brain cells, whereas focal seizure is the burst of electrical activity which starts and stays in one part of the brain, thus leading to localized symptoms [3].

The most common treatment for epilepsy is antiepileptic drugs (AEDs). They are used to control the convulsions by inhibiting the discharge and then producing hypnosis. Various synthetic AEDs are available in practice such as phenytoin, phenobarbital, carbamazepine, primidone, and valproate.

Certain drugs consist of various side effects which affect the central nervous system. They might also lead to idiosyncratic side effects which are usually rare and unpredictable which are not dose related. For example, phenytoin can cause the gums to swell and valproate can cause hair loss and weight gain. Thus, the current therapeutic treatment of epilepsy with modern AEDs is associated with side effects, dose-related and chronic toxicity, and teratogenic effects, with approximately $30 \%$ of the patients continue to have seizures with current AEDs therapy [4].

Plants have many medicinal properties due to the presence of various phytochemicals. In folk, medicine plants are used for the treatment of many disease conditions including epilepsy. The active constituents in plants show a direct pharmacological action on our body including various organs, having same mechanism of action as that of synthetic drugs [5]. Many essential oils extracted from plants have a significant effect on seizures by having a calm and relaxing effect [6].

There are a number of medicinal plants being used for the treatment of epilepsy such as Abelmoschus angulosus, Allium sativum, Artemisia spp., Cannabis sativa, Egletes viscosa, Magnolia grandiflora, and Xylopia spp. [7]. In this article, plants such as Aeollanthus suaveolens, Passiflora caerulea, Persea americana, Annona diversifolia, and Boerhavia diffusa are reviewed.

\section{DISCUSSION}

\section{A. suaveolens}

Aeollanthus is a genus in the mint family, Lamiaceae [8]. They are commonly found in Northern Nigeria, Sudan, East Africa, and Brazil. A. suaveolens is a succulent, annual herb growing $20-50 \mathrm{~cm}$ tall. It is a short-lived perennial herb that stays erect, bushy and can grow till $80 \mathrm{~cm} \mathrm{[6].} \mathrm{The} \mathrm{major} \mathrm{components} \mathrm{are} \mathrm{linalool,} \mathrm{2-decan-5-olide,} \mathrm{and}$ linalyl acetate [9] (Fig. 1).

In Africa, the leaves are stuffed into the ear like an earplug for relief from earaches. As a soothing tea, it can be used for menstrual cramps. In Northern Nigeria, for its aromatic foliage, it is used to flavor soup. In North-Eastern Brazil, it is used as a medicinal plant for the treatment of eye, ear, and skin infections. This herb has antimicrobial and anti-inflammatory properties too [10].

A study conducted on mice with the essential oil of $A$. suaveolens has reported dose-dependent marked effects on the central nervous system and anticonvulsant effect [11]. Another study with the flowers and leaves of the plant have showed a significant content of monoterpenes, 
which was then concluded to be reason for anticonvulsant and sedative properties.

\section{P. caerulea}

Passiflora belongs to the Passifloraceae family [12]. These plants are found mostly in South America, Australia, and Argentina. P. caerulea is a woody vine capable of growing to 15-20 m high where supporting trees are available. The leaves are alternate, palmate five-lobed like a spread hand, 10-18 cm long and wide (Fig. 2).

It contains flavonoids, alkaloids armalinici, and chrysin. Tetraphyllin B and epitetraphyllin B, and cyanogenic glycosides have been found in the leaves. It is eaten raw and can be used as a substitute for blackberries. They are also used in scent making. In South America, P. caerulea is mostly used to alleviate stress and anxiety [13].

In a study conducted recently prove that the anticonvulsant property of P. caerulea in the clonic seizure-pentylenetetrazole (PTZ) model. As the effect of this in clonic seizure, it is suggested to be a useful treatment of absent seizure. The mechanism of benzodiazepine receptor in P. caerulea is also known to be vital [14]. Similarly, a study conducted on chrysin was also found to be a ligand for the benzodiazepine receptors, when administered to mice by the intracerebroventricular route [15].

\section{P. americana}

P. americana, commonly known as avocado, belongs to the family Laureacea, is native to Central and S. America [16]. It is distributed in tropical and subtropical countries worldwide. It grows to a height of $20 \mathrm{~m}$. The single-seeded fruit which is $7-20 \mathrm{~cm}$ long has a leathery skin that ranges from yellow-green to purple. The mesocarp or pulp is edible and is yellow to yellow-green and has a buttery consistency (Fig. 3).
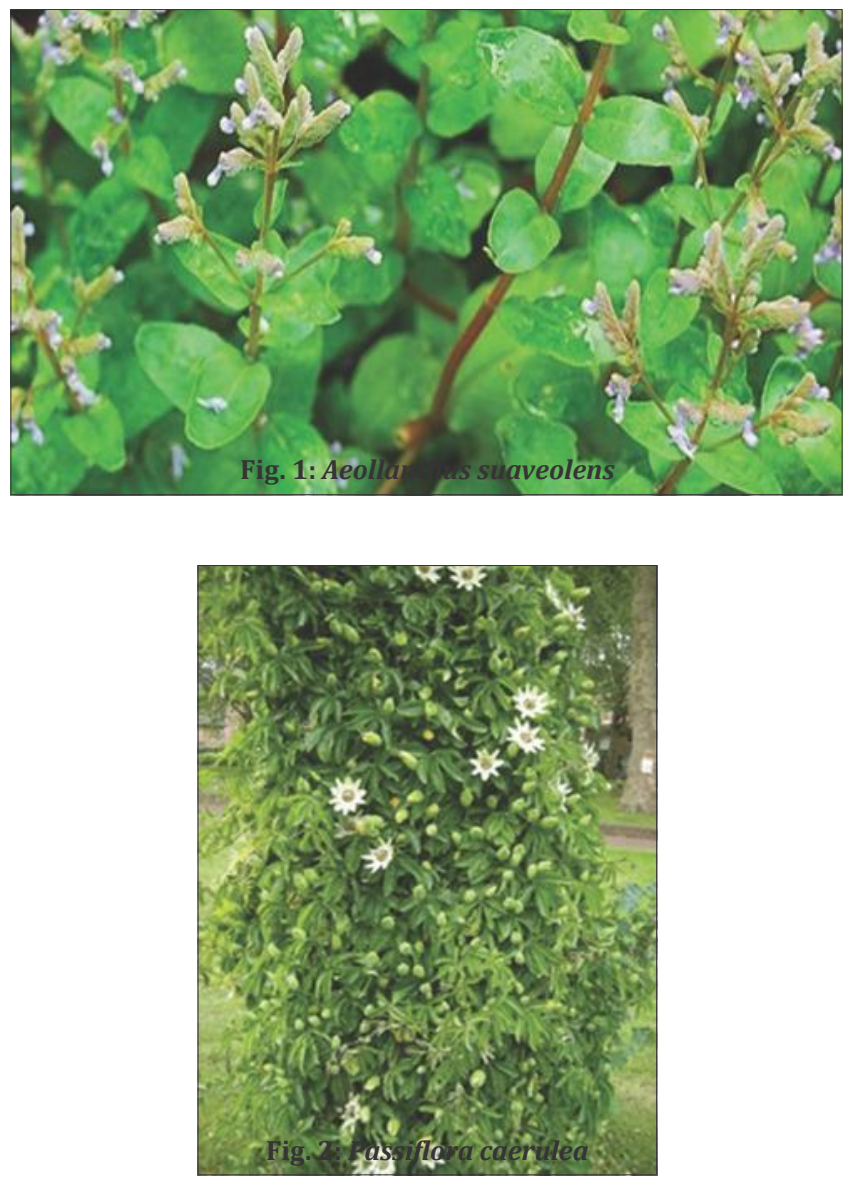

Avocados contain a number of bioactive phytochemicals including carotenoids, terpenoids, D-mannoheptulose, persenone A and B, phenols, and glutathione. The pulp contains $65-80 \%$ moisture, $1-4 \%$ protein, and $3-30 \%$ oil. The fruit contains many vitamins, minerals, stigmasterol, campesterol, and beta-sitosterol [17]. Avocado is useful for weight management, DNA damage protection, osteoarthritis, and cancer [16]. The plant is used in traditional medicine for the treatment of various ailments such as menorrhagia, hypertension, stomach ache, bronchitis, diarrhea, and diabetes [18].

Various morphological parts of P. americana are widely used in African traditional medicines for the treatment, management and/or control of a variety of human ailments, including childhood convulsions and epilepsy. A study indicated that the $P$. americana leaf aqueous extract possess an anticonvulsant property, which was conducted on mice against PTZ, picrotoxin (PCT), and bicuculline (BCL). It appeared that

"avocado" leaf aqueous extract produces its anticonvulsant effect by enhancing gamma-aminobutyric acid ergic (GABAergic) neurotransmission in the brain. The extract significantly delayed the onset of PTZ, and also profoundly antagonized PCT induced seizures but only weakly antagonized BCL induced seizures [19].

\section{Annona diversifolia}

Annona diversifolia belongs to the Annonaceae family [20]. It is basically originated indigenously in the mountains and foothills of South-Western Mexico, Guatemala, and Salvador. A diversifolia are evergreen or semi-deciduous, tropical trees or shrubs (Fig. 4).
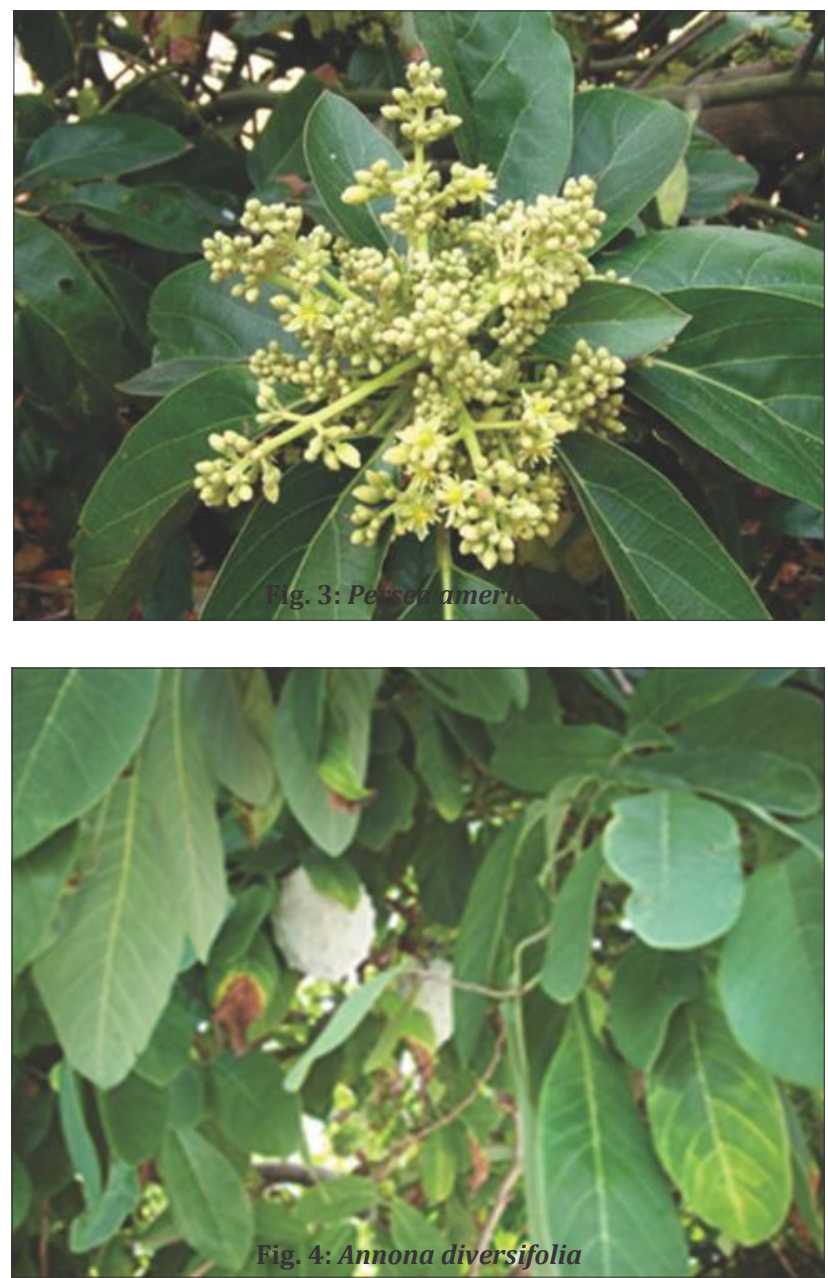


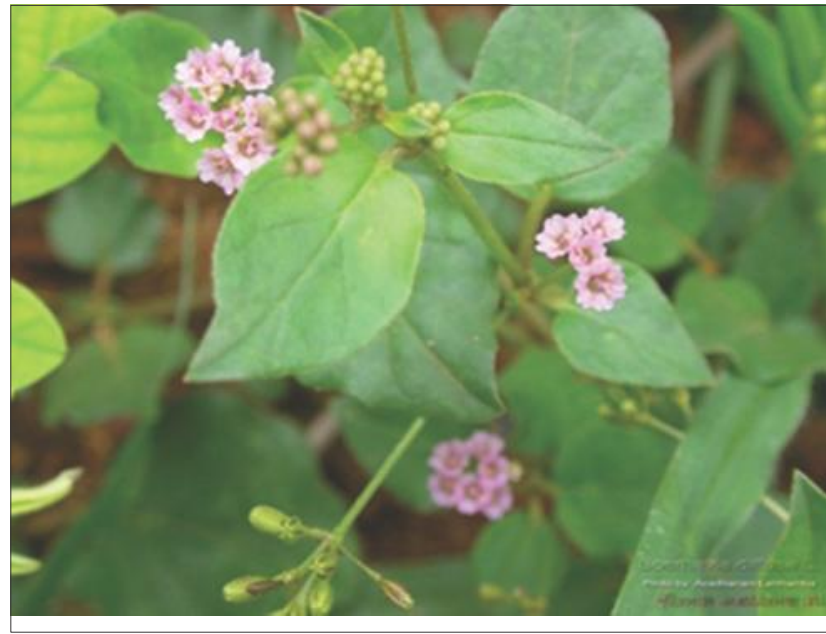

Fig. 5: Boerhavia diffusa

Annonas are consumed as fresh fruits but are widely used in folk medicine for treating pain and other ailments. It is composed of phenols and flavonoids [21]. The fruit has a sweet, aromatic, pleasant flavor and is eaten raw. The fruit is used also in jams, jellies, and preservatives.

In a study conducted by extracting the powder of Annona, led to the isolation of palmitone, which was found to be the anticonvulsant active compound it [22]. A. diversifolia's root bark aqueous extract significantly delayed the onset of seizures induced by pilocarpine as it had reportedly produced GABA neurotransmission by blocking the chloride linked channels linked to GABAA-receptors [23]. It was observed that it may also be due to one or more of the known mechanisms of anticonvulsant action, such as alteration of $\mathrm{Na}+\mathrm{k}+\mathrm{ATPase}$ expression and inhibition of expression of inducible nitric oxide.

\section{B. diffusa}

B. diffusa belongs to the family of Nyctaginace [24]. It is widely dispersed, throughout India, The pacific and southern United States. Diffusa is used as a green leafy vegetable in many Asian and African countries [24].

The plant is rich in lignans, xanthones, punarnavine, ursolic acid, and liriodendrin as well as retinoid [24]. B. diffusa has shown some in vitro anticancer, antiestrogenic, immunomodulatory, and antiamoebic activity. It has the ability to improve eyesight and has diuretic properties and is also known for controlling blood sugar levels in diabetic patients [24] (Fig. 5).

A study conducted on liriodendrin, which was isolated from the methanolic extract of roots of $B$. diffusa, have an anticonvulsant activity against the PTZ induced convulsions. It showed calcium channel antagonist activity, which may be the reason to the anticonvulsant property of $B$. diffusa. As this activity is retained only in the liriodendrin rich fraction, it proves its anticonvulsant property [25]

\section{CONCLUSION}

The majority of epileptic seizures are controlled by medication, particularly anticonvulsant drugs. The type of treatment will depend on several factors including severity, overall health conditions, and medical history. Plants are with different phytochemicals and some of it is with potent anticonvulsant effect. A. suaveolens (essential oil), P. caerulea, (chrysin) P. americana (leaf aqueous extract), Annona diversifolia (Plamitone), and B. diffusa (Liriodendrin) have proven anticonvulsant activity. Hence, these plants may be used as an alternative source to AEDs.

\section{REFERENCES}

1. Hauser WA. Epilepsy: Frequency, Causes and Consequences. New York: Demos; 1990. p. 1-51.

2. Kenny T. Epilepsy - A general introduction. 2015;41:4433

3. So EL. Classifications and epidemiolic considerations of

epileqetiizures and epilepsy. Neuroimag Clin N Am 1996;5(4):513-26.

4. Samren EB, van Duijn CM, Koch S, Hiilesmaa VK, Klepel H, Bardy $\mathrm{AH}$, et al. Maternal use of antiepileptic drugs and the risk of major congenital malformations: A joint European prospective study of human teratogenesis associated with maternal epilepsy. Epilepsia 1997;38(9):981-90.

5. Reetesh KM. Medicinal plants use in the treatment of epilepsy. Int Res J Pharm 2011;2(2):32-9.

6. de Almeida RN, Agra Mde F, Maior FN, de Sousa DP. Essential oils and their constituents: Anticonvulsant activity. Molecules 2011;16(3):2726-42.

7. Junior LJ, Almeida JR, Lima JT, Nunes XP, Siqueira JS, de Oliveira LE, et al. Plants with anticonvulsant properties - A review. Rev Bras Pharmacogn 2008; 18:

8. Porembski. Vegetation of inselbergs, quazitic outcrops and ferricretes in Rwanda and Eastern Zaire (Kivu). JSTOR

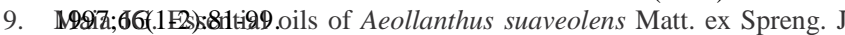
Essent Oil Res 2003;15(2):86-7.

10. Neuwinger HD. African Traditional Medicine: A Dictionary of Plant Use and Applications. Stuttgart, Germany: Medpharm Scientific; 2000. p. 589.

11. Coelho de Souza GP, Elisabetsky E, Nunes DS, Rabelo SK, Nascimento da Silva M. Anticonvulsant properties of gammadecanolactone in mice. J Ethnopharmacol 1997;58(3):175-81.

12. Ingale AG. Pharmcological studies of Passiflora sp. And their bioactive compounds. Afr J Plant Sci 2010;4(10):417-26.

13. Felieu-Hemmelmann K. Melissa offcinalis and Passiflora caerulea infurion as physiological stress decreser. Int J Clin Exp Med 2013;6(6):444-51.

14. Ingale AG, Hivrale AU. Pharmacological studies of Passiflora sp. And their bioactive compounds. Afr J Plant Sci 2010;4(10):417-26.

15. Medina JH, Paladini AC, Wolfman C, Levi de Stein M, Calvo D, Diaz LE, et al. Chrysin (5,7-di-OH-flavone), a naturally-occurring ligand for benzodiazepine receptors, with anticonvulsant properties. Biochem Pharmacol 1990;40(10):2227-31.

16. Yasir M, Das S, Kharya MD. The phytochemical and pharmacological profile of Persea americana Mill. Pharmacogn Rev 2010;4(7):77-84.

17. Arukwe U, Amadi BA, Duru MK, Agomuo EN, Adindu EA, Odika PC, et al. Chemical composition of Persea americana leaf, fruit and seed. Int J Res Rev Appl Sci 2012;11(2):346.

18. Duester KC. Avacado fruit is a rich source of beta-sitosterol. J Am Diet Assoc 2001;101(4):404-5.

19. Ojewole JA, Amabeoku GJ. Anticonvulsant effect of Persea americana Mill (Lauraceae) (avocado) leaf aquous extract in mice. Phytother Res 2006;20(8):696-700.

20. Germplasm Resources Information Netwerk (GRIN) (1996-09-17). Genus Annona L. Taxonomy for Plants. USDA ARS, National Genetic Resources Program. Bestville, Maryland: National Germplasm

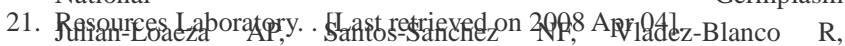
Sanchez-Guzman BS, Salas-Coronado R. Chemical composition, color and antioxidant activity of three varieties of Annona diversifolia afford fruits. Ind Crops Prod 2011;34(2):1262-8

22. Gonzalez-Trujano ME, Navarrette A, Reyes B, Cedillo-Portugal E, Hong E. Anticonvulsant propertied and bio-guided isolation of palmitone from leaves of Annona diversiflora. Planta Med 2001;67(2):136-41.

23. Gonzalez-Trujano ME, Navarrete A, Reyes B, Hong E. Some pharmacological effects of the ethanol extract of leaves of Annona diversiflora on the central nervous system in mice. Phytother Res 1998;12(8):600-2.

24. Mahesh AR, Kumar H, Ranganath MK, Devkar RA. Detail study on Boehavia diffusa plant for its medicinal importance - A review. Res J Pharm Sci 2012;1(1):28-36.

25. Kaur M, Goel RK. Anticonvulsant activity of Boerhavia diffusa: Plausible role of calcium channel antagonism. Evid Based Complement Alternat Med 2011;2011:7. 